Research Paper

\title{
Correlations between Oxidative DNA Damage, Oxidative Stress and Coen- zyme Q10 in Patients with Coronary Artery Disease
}

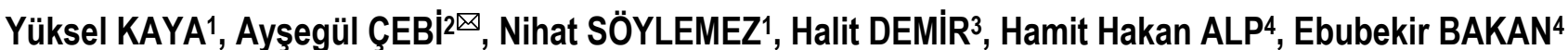

1. Kafkas University, Faculty of Medicine Department of Cardiology, Kars, Turkey.

2. Giresun University Faculty of Health Sciences, Giresun, Turkey.

3. Yüzüncü Yil University Faculty of Science Department of Biochemistry, Van, Turkey.

4. Atatürk University Faculty of Medicine Department of Biochemistry, Erzurum, Turkey.

Corresponding author: Dr. Ayşegül Çebi, Giresun University Faculty of Health Sciences. Piraziz, Giresun-Turkey. Tel: +904543613788

(C) Ivyspring International Publisher. This is an open-access article distributed under the terms of the Creative Commons License (http://creativecommons.org/ licenses/by-nc-nd/3.0/). Reproduction is permitted for personal, noncommercial use, provided that the article is in whole, unmodified, and properly cited.

Received: 2012.06.21; Accepted: 2012.09.05; Published: 2012.09.19

\begin{abstract}
The correlation of coronary artery disease (CAD) with pro-oxidant/antioxidant balance and oxidative DNA damage was investigated.

Seventy-seven patients with CAD and 44 healthy individuals as control were included in this study. The comparative ratios of ubiquinol-10/ubiquinone-10, 8-hydroxy-2'-deoxyguanosine/ deoxyguanosine and the level of MDA measured by HPLC and the activities of GPX and SOD by colorimetric approach in blood samples obtained from patients with CAD were unraveled. 8-OHdG/dG ratios, serum MDA level and GPX activity were found significantly elevated level in serum of CAD patients compared to control group. The SOD activity was observed in stable levels in CAD patients. Ubiquinol-10/ubiquinone-10 ratio was significantly lower in patients with CAD than the controls.

The positive correlation was observed between 8-OHdG/dG ratios in both MDA levels and GPX activity, while the significant negative correlation was seemed between the ratio of $8-\mathrm{OHdG} / \mathrm{dG}$ and ubiquinol-10/ ubiquinone-10 as well as MDA levels and ubiquinol-10/ ubiquinone- 10 ratio.

We conclude that, both the disruption of pro-oxidant/antioxidant balance and oxidative stress in DNA may play an important role in the pathogenesis of coronary artery disease.
\end{abstract}

Key words: CoenzymeQ10, 8-hydroxy-2'-deoxyguanosine, malondialdehyde, oxidative stress, antioxidants, coronary artery disease.

\section{INTRODUCTION}

Coronary artery disease (CAD) is one of the leading causes of morbidity and mortality in developed countries and is emerging as an epidemic in developing countries (1). It is well established that hypercholesterolemia is an important inducer of CAD (2). It has been known that there was a relation between the levels of DNA damage and the severity of the CAD (3). Published studies have demonstrated that DNA damage contributes significantly to the development and the progression of atherosclerosis $(4,5)$.

Lipid peroxidation, which is mediated by free radicals, is considered to be the major mechanism of cell membrane destruction and cell damage. Free radicals are formed in both physiological and pathological conditions in mammalian tissues $(6,7)$. The 
recent studies showed that malondialdehyde (MDA) is an important marker of lipid peroxidation and progression of atherosclerosis is correlated with oxidative stress and can be followed up by MDA measurements (8).

Cells have an efficient antioxidant defence system, mainly composed of the enzymes such as superoxide dismutase (SOD) and glutathione peroxidase (GPX), which can scavenge the reactive oxygen species (ROS) produced by cellular metabolism, and make ROS level relatively stable under physiological conditions. Superoxide dismutase catalytically scavenges superoxide radicals $\left(\mathrm{O}_{2}{ }^{-}\right)$, protecting against their potential cytotoxicity. It catalyzes the dismutation of highly reactive $\mathrm{O}_{2}{ }^{-}$, to $\mathrm{O}_{2}$ and $\mathrm{H}_{2} \mathrm{O}_{2}$, which is a less reactive ROS (9).

Remnants of base and sugar groups, single-double strand breaks in the backbone and cross links to other molecules are produced as a consequence of DNA oxidation. Among the many types of oxidative DNA damage markers, 8-hydroxy-2'-deoxyguanosine $(8-\mathrm{OHdG})$ is one of the most abundant oxidative products of cellular DNA damage. Since it can be detected by a high-performance liquid chromatography (HPLC) electrochemical detection method, it is sensitive and reliable $(10,11)$.

Coenzyme Q10 (CoQ10) is produced by the human body and is necessary for the basic functions of cells. CoQ10 is an important inhibitor of oxidative damage (12). The oxidized form of CoQ10 is called as ubiquinone-10, while the reduced form of CoQ10 is known as ubiquinol-10. It occurs in all cellular membranes, such as blood serum and serum lipoproteins. Ubiquinol offers efficient protection against the peroxidation of membrane phospholipids and serum low-density lipoproteins. Aside from its antioxidant role, CoQ10 is involved in electron transport and in adenine triphosphate synthesis associated with mitochondrial respiratory chain (13). Ubiquinol-10 is the first antioxidant to be oxidized when low-density lipoproteins are exposed to oxidants (14). Therefore, the ubiquinol-10/ubiquinone-10 ratio may be a sensitive marker for studying disturbances of the pro-oxidant-antioxidant balance in human blood (15). However, little is known about association of DNA damage with MDA, total antioxidant enzymes and CoQ10 in patients with CAD.

The aim of the present study was to investigate the relationship between oxidative DNA damage, pro-oxidant/antioxidant balance, lipid peroxidation and antioxidant enzymes in CAD. For this reason, we determined the 8-OHdG levels in leukocyte DNA as a specific marker of oxidative damage of DNA, serum
MDA levels as the index of lipid peroxidation, the serum GPX and SOD activities as antioxidant enzymes, ubiquinol-10/ ubiquinone-10 ratio as pro-oxidant-antioxidant balance in patients with CAD.

\section{PATIENTS AND METHODS}

\section{Patients}

Subjects who were older than 18 years and admitted to institutional outpatient clinic with a symptom compatible with chronic coronary artery disease and had an indication for coronary angiography were subsequently enrolled to this study. Patients who had $50 \%$ or more coronary stenosis in at least one major coronary artery were included in coronary artery disease group, while those with angiographically-normal appearing coronary arteries (without stenosis or ectasia) served as healthy controls. Subjects who had other cardiac diseases including cardiomyopathy, left ventricular systolic dysfunction or severe heart failure (New York Heart Association class III or IV symptoms), valvular heart disease, experienced acute coronary syndrome in the preceding 30 days before angiography or those with a history of percutenous coronary intervention were excluded. Other criteria for exclusion included acute or chronic inflammatory disorders, immunological diseases, renal or liver failure, and previous or current neoplastic disease. A total of 77 patients with coronary artery disease and 44 healthy controls that fulfilled criteria were enrolled.

Data regarding to medical history, including smoking habits, presence of hypertension, diabetes mellitus and hyperlipidemia were recorded for all subjects. Our study was approved by local ethics committee of Yuzuncu Yil University Medical Faculty and all subjects gave their written consent before enrollment. This study was in accordance with second Declaration of Helsinki.

\section{Samples}

Venous blood samples were drawn from each patient before coronary angiography process to avoid oxidative stress caused by X-rays, following an overnight fasting period. Serum was obtained by centrifugation at $2500 \mathrm{rpm}$ for 15 minutes and kept in deep freeze at $-20^{\circ} \mathrm{C}$ (without thawing) until the study day.

\section{Isolation and hydrolization of DNA}

DNA isolation from blood was performed with some modifications (16). Two $\mathrm{mL}$ of blood with ethylene diamine tetraacetic acid (EDTA) was mixed with $3 \mathrm{~mL}$ of erythrocyte lysis buffer, and incubation 
for $10 \mathrm{~min}$ in ice was followed by centrifugation (10 min at $3500 \mathrm{rpm}$ ). The supernatant was decanted, and the pellet was thoroughly resuspended in sodium dodecyl sulphate $(10 \%, \mathrm{v} / \mathrm{v})$, proteinase $\mathrm{K}(20$ $\mathrm{mg} / \mathrm{mL}$ ) and $1.9 \mathrm{~mL}$ leukocyte lysis buffer. The mixture was incubated at $65^{\circ} \mathrm{C}$ for $1 \mathrm{~h}$ and then mixed with $0.8 \mathrm{~mL}$ of $9.5 \mathrm{M}$ ammonium acetate. After centrifugation at $3500 \mathrm{rpm}$ for $25 \mathrm{~min}$, the clear supernatant $(2 \mathrm{~mL})$ was transferred to a new sterile tube, and DNA was precipitated by addition of $4 \mathrm{~mL}$ of ice-cold absolute ethanol. DNA samples were dissolved in Tris EDTA buffer (10 mM, pH 7.4), and then were hydrolyzed (17).

\section{Analysis of 8-OHdG and dG by the HPLC method}

In the hydrolyzed DNA samples, $8-\mathrm{OHdG}$ and dG levels were measured respectively by electrochemical HPLC (HPLC-ECD) and variable wavelength detector HPLC (HPLC-UV) systems as previously described (18). Twenty $\mu \mathrm{L}$ of final hydrolysate were analysed by HPLC-ECD (HP, Agilent 1100 modular systems with HP 1049A ECD detector, Germany): Column, reverse phase-C18 (RP-C18) analytical column $(250 \mathrm{~mm} \times 4.6 \mathrm{~mm} \times 4.0 \mu \mathrm{m}$, Phenomenex, $\mathrm{CA})$. The mobile phase consisted of $0.05 \mathrm{M}$ potassium phosphate buffer [pH 5.5] containing acetonitrile (97: $3, \mathrm{v} / \mathrm{v}$ ) with a flow rate of $1 \mathrm{~mL} / \mathrm{min}$. The dG concentration was monitored based on absorbance ( 245 $\mathrm{nm})$ and 8-OHdG based on the electrochemical reading $(600 \mathrm{mV})$. Levels of $\mathrm{dG}$ and $8-\mathrm{OHdG}$ were quantified using the standards of $\mathrm{dG}$ and $8-\mathrm{OHdG}$ from sigma; the level of 8 -OHdG was expressed as the number of 8-OHdG molecules per $106 \mathrm{dG}$.

\section{Analysis of MDA by HPLC method}

Measurement of serum MDA concentration was performed according to Khoschsorur et al. (19). Briefly, $50 \mu \mathrm{L}$ of plasma sample was mixed with 0.44 $\mathrm{M} \mathrm{H}_{3} \mathrm{PO} 4$ and $42 \mathrm{mM}$ tiobarbituric acid (TBA), and incubated for $30 \mathrm{~min}$ in a boiling water bath. After rapidly cooling on ice, an equal volume of alkaline methanol was added to the sample, vigorously shaken, centrifuged (3000 rpm for $3 \mathrm{~min}$ ), and the aqueous layer was removed. Then, $20 \mu \mathrm{L}$ supernatant was analysed by HPLC (HP, Agilent 1100 modular systems with FLD detector, Germany): Column, RP-C18 (5 $\mu \mathrm{m}$, $4.6 \times 150 \mathrm{~mm}$, Eclipse VDB- C18. Agilent); elution, methanol $(40: 60, \mathrm{v} / \mathrm{v})$ containing $50 \mathrm{mM} \mathrm{KH_{2 } \mathrm { PO } 4}$ buffer ( $\mathrm{pH}$ 6.8); flow rate, $0.8 \mathrm{~mL} / \mathrm{min}$. Fluorometric detection was performed with excitation at $527 \mathrm{~nm}$ and emission at $551 \mathrm{~nm}$. The peak of the MDA-TBA adduct was calibrated as a 1,1,3,3- tetraethoxypropane standard solution carried out in exactly the same process as with the plasma sample.

\section{Analysis of SOD activity by spectrophotomet- ric method}

Measurement of SOD enzyme activation was measured with Randox -Ransod enzyme kit and it was measured with autoanalyzer at $505 \mathrm{~nm}$ and $37^{\circ} \mathrm{C}$. Ten $\mu \mathrm{l}$ was taken from erythrocyte suspension and mixed with $2500 \mu 10.01 \mathrm{M}$ phosphate $(\mathrm{pH}=7.0)$. Later, it was diluted 251 times with water $(F=251)$. Inhibition was obtained between $30-60 \%$ (20).

\section{Analysis of GPX activity by spectrophotomet- ric method}

Measurement of GPX enzyme activation was performed according to Paglia and Valentina (21). GPX enzyme catalyzes oxidation of glutathione. When the oxidized glutathione is reduced, NADPH is oxidized and it is turned into NADP. This change was observed at $340 \mathrm{~nm}$ wave and activation of GPX was measured.

\section{Analysis of Coenzyme Q10 by the HPLC method}

Analyses of ubiquinol-10 and ubiquinon-10 were performed according to Mosca et al (22). This method is performed by forcing the oxidation of CoQ10 in the sample by treating it with para-benzoquinone followed by extraction with 1-propanol and direct injection into the HPLC apparatus. Pre-oxidation of the sample ensures quantification of total CoQ10 by UV detection. This method achieves a linear detector response for peak area measurements over the concentration range of 0.05 to $3.47 \mu \mathrm{mol} / \mathrm{L}$. Diode array analysis of the peak level was consistent with the CoQ10 spectrum. Supplementation of the samples with known amounts of CoQ10 yielded a quantitative recovery of $96 \%$ to $98.5 \%$; the method showed a level of quantitation of $1.23 \mathrm{nmol}$ per HPLC injection (200 $\mu \mathrm{L}$ of propanol extract containing $33.3 \mu \mathrm{L}$ of plasma). A good correlation was found with a reference electrochemical detection method $(\mathrm{r}=0.99, \mathrm{P} \quad \mathrm{b}$.0001). Within-run precision showed a coefficient of variation of 1.6 for samples approaching normal values (1.02 $\mu \mathrm{mol} / \mathrm{L})$. Day-to-day precision was also close to $2 \%$. The reference values of CoQ10 are 0.7 to $1 \mu \mathrm{g} / \mathrm{mL}$ (23). Moreover, CoQ10 values were compared to plasma cholesterol concentration, measured by a cholesterol-oxidase enzymatic test.

\section{Statistics}

Data were presented as mean \pm standard deviation (SD). A non-parametric Mann Witney U-test was used to evaluate the significance of differences. 
Spearman's correlation coefficients were used to calculate the association between the changes of groups.

\section{RESULTS}

The demographic characteristics of the groups are listed in Table 1 . The mean age, gender, body mass index, smoking, hypertension and diabetes mellitus were similar in both groups. There was no difference in total, LDL, HDL cholesterol, triglyceride and creatinine values between patients and controls.

It was observed that there was a significant increase in the ratio of 8-OHdG/dG, the level of MDA and GPX activity in patients with CAD when compared to controls $(p<0.001)$. Otherwise, the ratio of ubiquinol-10/ubiquinone-10 was significantly lower in patients with CAD when compared to controls $(p<0.001)$ (Table 2). However, SOD activity was found similar in both groups $(p=0.779)$ (Table 2$)$.

In addition multivariate linear regression analysis showed a positive correlation between $8-\mathrm{OHdG} / \mathrm{dG}$ ratio and MDA levels $(\mathrm{r}=0.306, \mathrm{p}<0.01)$ and GPX activity $(\mathrm{r}=0.563, \mathrm{p}<0.01)$, while there was a significant negative correlation between the ratio of 8-OHdG/dG and the ratio ubiquinol-10/ ubiquinone-10 $(\mathrm{r}=-0.514, \mathrm{p}<0.01)$ (Table 3). However, there was a negative correlation between MDA levels and ubiquinol-10/ ubiquinone-10 ratio $(\mathrm{r}=-0.190, \mathrm{p}<0.05)$ (Table 3).

Table I. Clinical characteristics of the study population.

\begin{tabular}{|c|c|c|c|}
\hline & $\begin{array}{l}\text { Patients with } \\
\text { CAD } \\
(\mathrm{n}=77)\end{array}$ & $\begin{array}{l}\text { Control group } \\
(n=44)\end{array}$ & $P$ value \\
\hline Age (year) & $56.0 \pm 7.8$ & $54.3 \pm 10.2$ & 0.307 \\
\hline Sex (male) & $51(\%$ 66.2) & $31(\%$ 66.0) & 0.975 \\
\hline $\begin{array}{l}\text { Body mass index } \\
\left(\mathrm{kg} / \mathrm{m}^{2}\right)\end{array}$ & $27.5 \pm 3.8$ & $26.9 \pm 3.3$ & 0.314 \\
\hline Smoking (n) & $12(\% 15.6)$ & $8(\% 17.0)$ & 0.833 \\
\hline Hypertension (n) & $28(\% 36.4)$ & $12(\% 25.5)$ & 0.584 \\
\hline Diabetes mellitus (n) & $10(\%$ 13.0) & $4(\% 8.5)$ & 0.445 \\
\hline $\begin{array}{l}\text { Total cholesterole } \\
(\mathrm{mg} / \mathrm{dl})\end{array}$ & $190.5 \pm 38.5$ & $200.0 \pm 41.4$ & 0.208 \\
\hline Triglyceride (mg/dl) & $183.2 \pm 87.8$ & $192.7 \pm 125.2$ & 0.650 \\
\hline $\begin{array}{l}\text { LDL cholesterol } \\
(\mathrm{mg} / \mathrm{dl})\end{array}$ & $115.5 \pm 31.4$ & $124.9 \pm 44.5$ & 0.206 \\
\hline $\begin{array}{l}\text { HDL cholesterol } \\
(\mathrm{mg} / \mathrm{dl})\end{array}$ & $41.3 \pm 9.8$ & $44.2 \pm 10.3$ & 0.124 \\
\hline Creatinine (mg/dl) & $0.90 \pm 0.17$ & $0.87 \pm 0.13$ & 0.292 \\
\hline
\end{tabular}

Table 2. Comparison of the plasma levels of $8-O H d G / d G$ and the serum malondialdehyde (MDA), the serum glutathione peroxidase (GPX), superoxide dismutase (SOD), ubiqinol-10/ubiquinone-10 between patients with coronary artery disease $(C A D)$ and control group.

\begin{tabular}{|c|c|c|c|}
\hline & $\begin{array}{l}\text { Patients with } \\
\text { CAD (n=77) } \\
\text { Mean } \pm S D \\
\text { (min-max) }\end{array}$ & $\begin{array}{l}\text { Control } \\
(\mathrm{n}=44) \\
\text { Mean } \pm S D \\
(\min -\max )\end{array}$ & $P$ value \\
\hline 8-OHdG/dG & $\begin{array}{l}3.01 \pm 1.77 \\
(0.95-8.98)\end{array}$ & $\begin{array}{l}0.28 \pm 0.14 \\
(0.12-0.96)\end{array}$ & 0.000 \\
\hline MDA (umol) & $\begin{array}{l}11.27 \pm 9.05 \\
(0.64-38.88)\end{array}$ & $\begin{array}{l}4.86 \pm 2.75 \\
(0.14-12.34)\end{array}$ & 0.000 \\
\hline $\mathrm{GPX}(\mathrm{U} / \mathrm{mL})$ & $\begin{array}{l}26.75 \pm 10.78 \\
(7.58-50.74)\end{array}$ & $\begin{array}{l}10.46 \pm 6.07 \\
(2.04-22.90)\end{array}$ & 0.000 \\
\hline $\mathrm{SOD}(\mathrm{U} / \mathrm{mL})$ & $\begin{array}{l}6.32 \pm 4.00 \\
(0.3-17.9)\end{array}$ & $\begin{array}{l}6.54 \pm 4.44 \\
(0.2-18.2)\end{array}$ & 0.779 \\
\hline Ubiquinol-10/Ubiquinon-10 & $\begin{array}{l}0.49 \pm 0.34 \\
(0.11-1.89)\end{array}$ & $\begin{array}{l}1.23 \pm 0.84 \\
(0.45-3.92)\end{array}$ & 0.000 \\
\hline
\end{tabular}

Table 3. Spearman's correlation coefficients among variable.

\begin{tabular}{llllll}
\hline & $\begin{array}{l}8 \mathrm{OHdG} \\
/ \mathrm{dG}\end{array}$ & $\begin{array}{l}\text { MDA } \\
(\mu \mathrm{mol} / \mathrm{l})\end{array}$ & $\begin{array}{l}\text { Ubiq- } \\
\text { uinol-10/ } \\
\text { Ubiqui- } \\
\text { none-10 }\end{array}$ & $\begin{array}{l}\text { GPX } \\
(\mathrm{EU} / \mathrm{ml})\end{array}$ & $\begin{array}{l}\mathrm{SOD} \\
(\mathrm{EU} / \\
\mathrm{ml})\end{array}$ \\
\hline 8OHdG/dG & 1 & & & & \\
MDA $(\mu \mathrm{mol} / \mathrm{l})$ & $0.306^{* *}$ & 1 & & & \\
Ubiquinol-10/ & $-0.514^{* *}$ & $-0.190^{*}$ & 1 & & \\
Ubiquinone-10 & & & & & \\
GPX $(\mathrm{EU} / \mathrm{ml})$ & $0.563^{* *}$ & 0.106 & -0.471 & 1 & \\
SOD $(\mathrm{EU} / \mathrm{ml})$ & 0.007 & -0.031 & -0.151 & -0.006 & 1 \\
\hline
\end{tabular}

Correlation is significant at the 0.01 level (2-tailed), *Correlation is significant at the 0.05 level (2-tailed). $8-\mathrm{OHdG} / \mathrm{dG}=$ 8-hydroxy-2'-deoxyguanosine/deoxyguanosine; $\mathrm{MDA}=$ malondialdehyde; GPX = glutathione peroxidase; $\mathrm{SOD}=$ superoxide dismutase.

\section{DISCUSSION}

In the present study, DNA damage marker 8-OHdG/dG was significantly increased and the ratio of ubiqinol-10/ubiquinone-10 as a pro-oxidant/ oxidant marker was significantly decreased in patients with CAD when compared with controls. Also, the antioxidant GPX activity was increased in CAD patients.

DNA damage is caused by multiple factors including oxidative stress, Vitamin $B_{12}$ deficiency and ischemia-reperfusion injury $(3,4,6)$. The ratio of $8-\mathrm{OHdG} / \mathrm{dG}$ is correlated with the severity of the oxidative stress. The higher activity of an antioxidant 
enzyme may be a compensatory regulation in response to increased oxidative stress. In our previous study, we demonstrated that 8-OHdG may be a good biomarker for risk assessment of subclinical cardiovascular disease in haemodialysis patients (24). DNA damage has been related with the development of cardiovascular pathologies in the general population, which is supported for the monoclonal origin of cells from human atherosclerotic plaques (25).

In the present study, the lipid peroxidation product i.e. MDA levels have been increased significantly in plasma of the patients with coronary artery disease as compared to the controls. Raharjo et al. (26) reported that MDA is an important marker of lipid peroxidation. Belch et al. (27) showed that progression of atherosclerosis is correlated with oxidative stress and can be followed up by MDA measurements. Results of the studies of Pezeshkian et al. (28) showed that, MDA levels increased significantly in heart diseases. Some other investigates have also reported increase of SOD, MDA and GPX levels in patients with CAD (7). In our study, similar with the literature, the serum levels of MDA were found significantly higher in patients than that of the controls $(p<0.001)$. In our previous study, we showed that the serum levels of retinol, tocopherol and cholecalciferol concentrations were lower in CAD patients than that of the healthy control group (29).

Antioxidant enzymes (SOD, GPX) are compounds that dispose, scavenge, and suppress the formation of free radicals and oppose their actions. Two main categories of antioxidants prevent the generation of free radicals and those intercept any free radicals that are generated $(7,30,31)$. SOD is an important antioxidant enzyme having antitoxic effect against superoxide anion. GPX, an oxidative stress inducible enzyme, plays a significant role in peroxyl scavenging mechanism, and in maintaining functional integration of the cell membranes. Alteration in the oxidant - antioxidant profile is known to occur in CAD $(3,4)$. We have found that in the present study, GPX enzyme activation was significantly higher in patients with CAD than controls. However, SOD enzyme activation was similar in patients with CAD and in controls.

CoQ10, also known as ubiquinol-10, plays a central role in the mitochondrial respiratory system, in which it shuttles electrons from complexes I and II to complexes III. CoQ is an ubiquitous constituent of cellular membranes and functions as an antioxidant. It is also a modulator of the mitochondrial permeability transition pore (32). CoQ10 aids them by supplying energy for the function of cells with high metabolic demands, such as heart muscle. The correlation be- tween oxidative damage and mitochondrial alterations is strong. In our study, the ratio of $8-\mathrm{OHdG} / \mathrm{dG}$ and MDA were significantly negatively correlated with the ratio of ubiquinol-10/ ubiquinone-10 in CAD. These observations propose that oxidative dysfunction occurs in the pathogenesis of CAD and are consistent with the process of lipid peroxidation and oxidative DNA damage. Blood levels of CoQ10 were significantly lower in patients with ischemic heart disease and in those with dilated cardiomyopathy as compared to the healthy controls (33). Mabuchi et al., (34) reported that serum levels of CoQ10 diminished during treatment with statin in patients with hypercholesterolemia. CoQ10 levels are reported to decrease in patients with some chronic diseases such as heart disease.

In a clinical study, the administration of CoQ10 to heart transplant candidates led to a significant improvement in functional status, clinical symptoms, and quality of life. However, there were no objective changes in echo measurements or ANF and TNF blood levels. Coenzyme Q10 may serve as an optional addition to the pharmacologic armamentarium of patients with end-stage heart failure (35). In a double-blind trial, 144 people who had recently experienced a heart attack were given either placebo or 120 $\mathrm{mg}$ of CoQ10 daily for 1 year, along with conventional treatment. The results showed that participants receiving CoQ10 experienced significantly fewer heart-related problems, such as episodes of angina pectoris or arrhythmia, or recurrent heart attacks $(36,37)$. CoQ10's best-established use is for congestive heart failure, but the evidence is not compatible with proven benefit.

In conclusion, the present study revealed up-regulation of lipid peroxidation, oxidative DNA damage and deficiency of CoQ10 ratio in CAD. It causes to disrupt pro-oxidant/antioxidant balance and therefore CoQ10 supplementation may show cardioprotective effects in CAD.

\section{Competing Interests}

The authors have declared that no competing interest exists.

\section{References}

1. Yusoff K. Vitamin E in cardiovascular disease: has the die been cast? Asia Pac J Clin Nutr. 2002;11:443-447.

2. Kagan A, Kannel WB, Dawber TR, Revotskie N. The Coronary Profile. Ann N Y Acad Sci. 1963;97:883-894.

3. Demirbag R, Yilmaz R, Kocyigit A. Relationship between DNA damage, total antioxidant capacity and coronary artery disease. Mutat Res. 2005;570:197-203

4. Andreassi MG, Botto N, Cocci F, Battaglia D, Antonioli E, Masetti S, Manfredi S, Colombo MG, Biagini A, Clerico A. Methylenetetrahydrofolate reductase gene $\mathrm{C} 677 \mathrm{~T}$ polymorphism, homocysteine, vitamin B12, 
and DNA damage in coronary artery disease. Hum Genet. 2003;112:171-177.

5. Ross R. Atherosclerosis-an inflammatory disease. N Engl J Med. 1999;340:115-26.

6. Tas F, Hansel H, Belce A, Ilvan S, Argon A, Camlica H, Topuz E. Oxidative stress in breast cancer. Med Oncol. 2005;22:11-15.

7. Priya VV, Surapaneni KM. Erythrocyte lipid peroxidation, glutathione, ascorbic acid, vitamin E, antioxidant enzymes and serum homocysteine levels in patients with coronary artery disease. Journal of Clinical and Diagnostic Research 2008;2:1180-1185.

8. Mogadam RAP, Nemati A, Baghi AN. Serum MDA as a Diagnostic's Biomarker in Stable Coronary Heart Disease. Research Journal of Biological Sciences. 2008;3:206-210.

9. Halliwell B. Free radicals, antioxidants, and human disease: curiosity, cause, or consequence? Lancet. 1994;344:721-724.

10. Beckman KB, Ames BN. Oxidative decay of DNA. J Biol Chem. 1997; 272:19633-19636.

11. Kasai H. Analysis of a form of oxidative DNA damage, 8-hydroxy-2'deoxyguanosine, as a marker of cellular oxidative stress during carcinogenesis. Mutat Res. 1997; 387:147-163.

12. Ernster L, Dallner G. Biochemical, physical and medical aspects of ubiquinone functions. Biochim Biophys Acta 1995;1271:195-204.

13. Crane F, Sun IL, Sun EE: The essential function of coenzyme Q10. Clin Invest 1993;71:55-59.

14. Stocker R, Bowry VM, Frei B: Ubiquinol-10 protects human low density lipoprotein more efficiently against lipid peroxidation than does alpha-tocopherol. Proc Natl Acad Sci USA 1991;88:1646-1650.

15. Yamashita S, Yamamoto Y: Simultaneous detection of ubiquinol and ubiquinone in human plasma as a marker of oxidative stress. Anal Biochem 1997;250:66-73.

16. Khrosrow A, Godwin O. Rapid Purification of Human DNA from Whole Blood for Potential Application in Clinical Chemistry Laboratories. Clin Chem 1990;36:261-264.

17. Miller SA, Dykes DD, Polesky HF. A simple salting out procedure for extracting DNA from human nucleated cells. Nucleic Acids Res 1988;11:1215.

18. Shigenaga MK, Aboujaoude EN, Chen Q \& Ames BN. Assays of oxidative DNA damage biomarkers 8-oxo-2'-deoxyguanosine and 8-oxoguanine in nuclear DNA and biological fuids by high-performance liquid chomatography with electrochemical detection. Methods Enzymol 1994; 234:16-33.

19. Khoschsorur GA, Winklhofer-Roob BM, Rabl H, Auer Th, Peng Z, Schaur RJ. Evaluation of a Sensitive HPLC Method for the Determination of Malondialdehyde, and Application of the Method to Different Biological Materials. Chromatographia. 2000;52:181-184.

20. Armstrong D. Free radical and antioxidant protocols. Introduction. Methods Mol Biol. 1998;108:5-8.

21. Paglia DE, Valentine WN. Studies on the quantitative and qualitative characterization of erythrocyte glutathione peroxidase. J Lab Clin Med. 1967;70:158-169.

22. Mosca F, Fattorini D, Bompadre S, Littarru GP. Assay of coenzyme Q(10) in plasma by a single dilution step. Anal Biochem. 2002;305:49-54.

23. Tomasetti M, Alleva R, Solenghi MD, et al. Distribution of antioxidants among blood components and lipoproteins: significance of lipids/CoQ10 ratio as a possible marker of increased risk for atherosclerosis. Biofactors 1999;9:231-40.

24. Ari E, Kaya Y, Demir H, Cebi A, Alp HH, Bakan E, Odabasi D, Keskin S. Oxidative DNA damage correlates with carotid artery atherosclerosis in hemodialysis patients. Hemodial Int. 2011; 15: 453-459.

25. Botto N, Masetti S, Petrozzi L, Vassalle C, Manfredi S, Biagini A, Andreassi MG. Elevated levels of oxidative DNA damage in patients with coronary artery disease. Coron Artery Dis. 2002;13:269-274.

26. Raharjo S, Sofos JN, Schmidt GR. Solid-phase acid extraction improves thiobarbituric acid methods to determine lipid oxidation. J Food Sci. 1993;58:921-924.

27. Belch JJ, Mackay IR, Hill A, Jennings P, McCollum P. Oxidative stress is present in atherosclerotic peripheral arterial disease and further increased by diabetes mellitus. Int Angiol. 1995;14:385-388.

28. Pezeshkian M, Nouri M, Zahraei M, Afrasiabi A, Abadi NA. Study of MDA, antioxidant vitamins, lipoproteins serum levels and anthropometry parameters in coronary artery disease patients. Medical Journal of Islamic Academy of Sciences. 2001;14:5-8.

29. Cebi A, Kaya Y, Gungor H, Demir H, Yoruk IH, Soylemez N, Gunes Y, Tuncer M. Trace elements, heavy metals and vitamin levels in patients with coronary artery disease. Int J Med Sci. 2011; 8(6): 456-60.

30. Sies H. Oxidative stress: from basic research to clinical application. Am J Med. 1991;91:31-38.
31. Cotgreave IA, Moldéus P, Orrenius S. Host biochemical defense mechanisms against prooxidants. Annu Rev Pharmacol Toxicol. 1988;28:189-212.

32. Artuch R, Salviati L, Jackson S, et al. Coenzyme Q10 deficiencies in neuromuscular diseases. Adv Exp Med Biol. 2009; 652:117-128.

33. Langsjoen PH, Langsjoen PH, Folkers K. Long-term efficacy and safety of coenzyme Q10 therapy for idiopathic dilated cardiomyopathy. Am J Cardiol. 1990;65(7):521-3.

34. Mabuchi H, Higashikata T, Kawashiri M, Katsuda S, Mizuno M, Nohara A, Inazu A, Koizumi J, Kobayashi J. Reduction of serum ubiquinol-10 and ubiquinone-10 levels by atorvastatin in hypercholesterolemic patients. J Atheroscler Thromb. 2005;12(2):111-9.

35. Berman M, Erman A, Ben-Gal T, Dvir D, Georghiou GP, Stamler A, Vered Y, Vidne BA, Aravot D. Coenzyme Q10 in patients with end-stage heart failure awaiting cardiac transplantation: a randomized, placebo-controlled study. Clin Cardiol. 2004;27:295-299.

36. Singh RB, Wander GS, Rastogi A, Shukla PK, Mittal A, Sharma JP, Mehrotra SK, Kapoor R, Chopra RK. Randomized, double-blind placebo-controlled trial of coenzyme Q10 in patients with acute myocardial infarction. Cardiovasc Drugs Ther. 1998;12:347-353.

37. Singh RB, Neki NS, Kartikey K, Pella D, Kumar A, Niaz MA, Thakur AS. Effect of coenzyme Q10 on risk of atherosclerosis in patients with recent myocardial infarction. Mol Cell Biochem. 2003;246:75-82. 